\title{
転移性汗腺癌
}

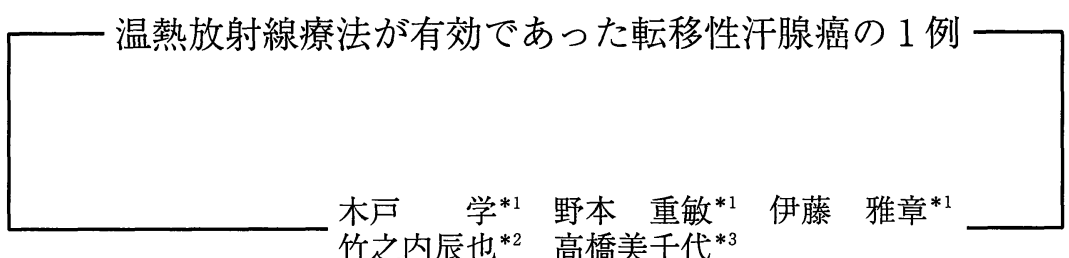
竹之内辰也 ${ }^{* 2}$ 高橋美千代*3

\section{Metastatic sweat gland carcinoma successfully treated with thermoradiation therapy}

Manabu KIDO*1, Shigetoshi NOMOTO*1, Masaaki ITO*', Tatsuya TAKENOUCHI*2, Michiyo TAKAHASHI*3

*1 Department of Dermatology, Niigata University School of Medicine

*2 Division of Dermatology, Niigata Cancer Center Hospital

*3 Division of Dermatology, Shibata Prefectural Hospital

A 73-year-old female presented with a small ulcerated nodule on her left heel. It was excised with a margin of $10 \mathrm{~mm}$ and reconstructed by skin grafting. The histological diagnosis was sweat gland carcinoma. Four months after the operation, a rapidly growing subcutaneous tumor was recognized on her left leg. The biopsy specimen showed metastatic sweat gland carcinoma. A combination therapy of intravenous cisplatin, 5-fluorouracil and subcutaneous peplomycin with 30Gy of irradiation was tried, but the patient could not endure its severe side effects. Subsequently, she was treated with $30.5 \mathrm{~Gy}$ of additional irradiation combined with hyperthermia. A great response was observed. Wide local excision and left groin dissection followed. There was no evidence of metastasis during 5 years after the therapy. [Skin Cancer (Japan) 2002 ; 17:123-126]

Key words : Sweat gland carcinoma, Thermoradiation therapy

\begin{abstract}
はじめに
汗腺癌は, 有棘細胞癌に比べ, 放射線治療に 対する感受性が低いとされ ${ }^{1)}$ ，原発巣に対して 放射線治療が第一選択となることは少ない。し
\end{abstract}

かし, 進行例では転移巣に対して積極的に放射 線照射が行われ，一定の効果が認められている ${ }^{2)}$ 今回我々は, 温熱放射線療法が有効であった転 移性汗腺癌の 1 例を経験したので報告する。

\section{症例}

*1 新潟大学皮膚科

*2 新潟がんセンター皮虐科

*3 県立新発田病院皮膚科
患 者: 73 歳, 女性

初診: 1995 年 10 月 19 日 
家族歴：特記すべきことなし。

既往歴：特記すべきことなし。

現病歴：初診の約 10 年前より,左踵部に結節 を生じ, 徐々に増大した。1995 年 4 月頃より潰 瘍を伴うようになり，同年 10 月，県立新発田病 院皮膚科を受診した。生検の結果，上皮系悪性 腫瘍が疑われ, 当科を紹介された。初診時, 左 踵部に潰瘍を伴う径 $15 \times 14 \mathrm{~mm}$ の赤色の扁平隆

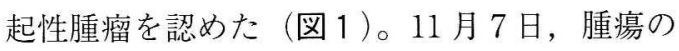
辺縁より $10 \mathrm{~mm}$ 離し, 筋膜上で切除し, 全層植 皮術を行った。切除標本の組織学的検索により 汗腺癌と診断した。画像診断上, 転移を示唆す る所見を認めず，治癒切除であったため，その 後は当科外来で経過観察を行っていた。術後 4 力月頃より, 左下腿外側に皮下腫瘤が出現 し, 徐々に増大した。生検の結果, 左踵部の腫 瘍と同様の組織像を示していたため, 転移性汗 腺癌と診断した。加療目的に 1996 年 5 月 7 日入 院した。

入院時現症: 左下腿外側に径 $3 \mathrm{~cm}$ 大で潰瘍を 伴う弾性硬の皮下腫瘤を認めた(図2a)。脛骨と 癒着し可動性不良であった。左鼠径リンパ節の 有意な腫大は認められなかった。
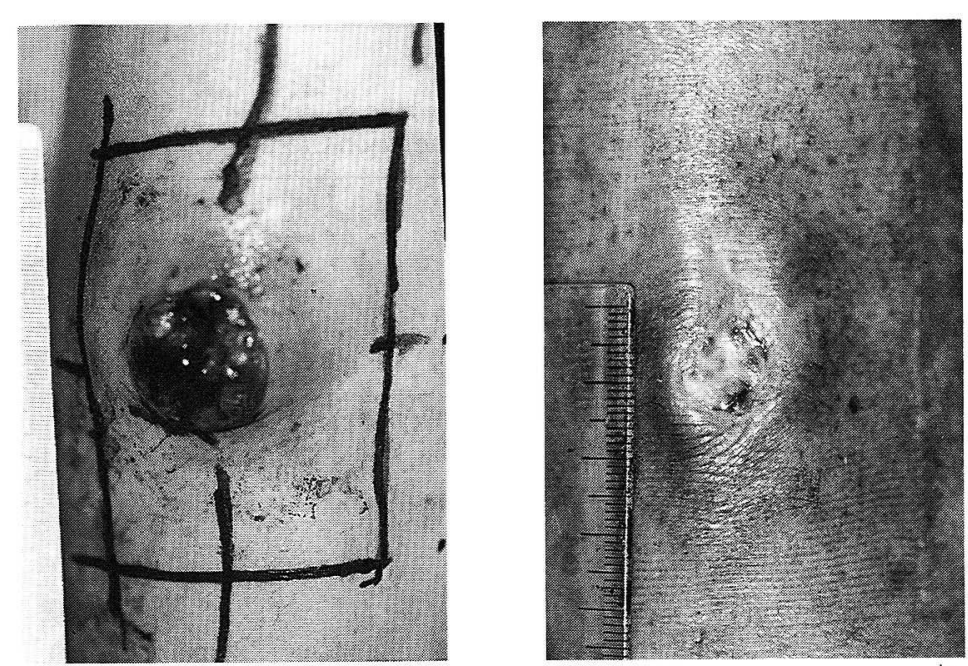

図 2、転移巣への温熱放射線療法

a. 施行前. 左下腿の径 $3 \mathrm{~cm}$ 大の潰瘍を伴う皮下腫瘤

b. 施行後. 腫瘤は小潰瘍を残して消失
入院時検查所見：腫瘍部の CT 所見で骨破壊 像を認めず，腹部・骨盤部 CT, 胸部 X 線上, 転移巣を認めなかった。

病理組織学的所見：原発巣は, 真皮全層に腫 瘍胞巣を認め，一部に管腔様構造を認めた（図 3)。個々の細胞は好酸性の胞体と異型性の強 い核を有していた。免疫組織化学的所見では,

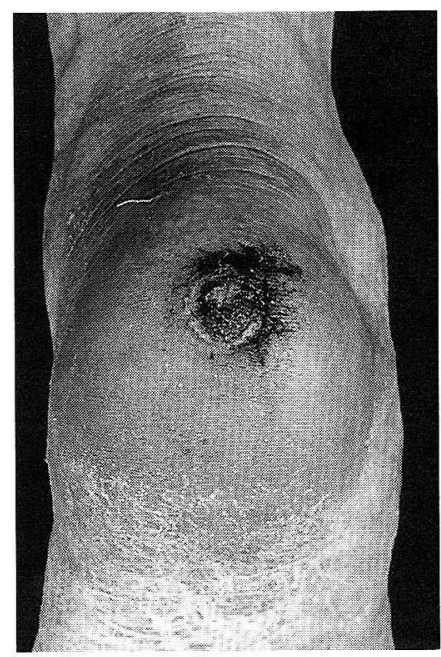

図 1, 原発巣臨床像 左踵部の赤色の扁平隆起性腫瘤 


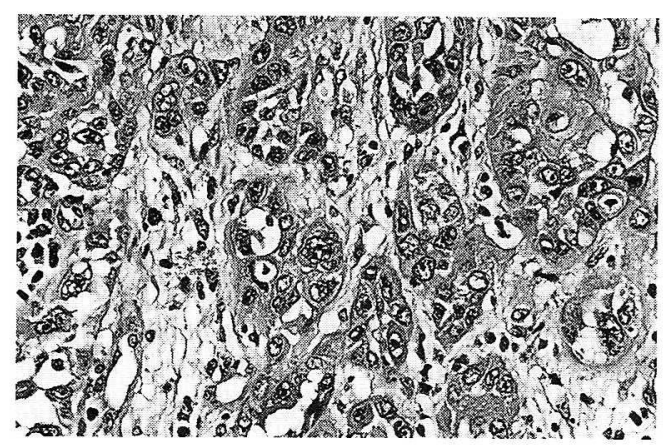

図 3. 原発巣病理組織像

ヘマトキシリン，エオジン染色．腫瘍細胞は 索状ないし同心円状に配列し，管腔様構造を 示す

管腔を構成する細胞の一部は CEA 陽性で汗器 官への分化を示唆した。腫瘍中央部の被覆表皮 は潰瘍化していたため，表皮との連続性は不明 であったが，本腫瘍を原発性の汗腺癌と診断し た。

転移巣は, 皮下脂肪織から筋膜にかけて腫痬 胞巣を認めた。管腔様構造を示し，左踵部の腫 瘍と同様の組織像を示していたため, 転移性汗 腺癌と診断した（図 4)。

治療および経過：腫瘍の縮小効果をねらっ て, 5 月 13 日から $\operatorname{CDDP}(15 \mathrm{mg} /$ day, day 1-7), $5-\mathrm{FU}$ (1000mg/day, day 1-5), PEP (5mg/day, day 1-5）の 3 剂併用による化学療法を 1 タール 施行し, 5 月 14 日よりコバルト照射を併用した。 30Gy 照射後の 5 月 24 日に施行したCTで，腫 瘤内部が低吸収域となり, 壊死の進行が示唆さ れたが，嘔気等の副作用により化学療法の継続 が困難であった。さらに $30.5 \mathrm{~Gy}$ のコバルト照射 を行うとともに，6月 3 日から温熱療法の併用 を開始した。マイクロ波を用いて腫瘤直下を $43^{\circ} \mathrm{C}$ で約 1 時間加温し，これらを 1 クールとし て, 週 2 回の頻度で計 4 クール施行した。温熱 療法開始後 1 カ月で, 腫瘍は著明に縮小し外観 上はほぼ消失した（図 2 b)。 8 月 1 日，広範囲 切除術，皮弁作成術掞よび左鼠径リンパ節郭清 術を施行した。腫瘍直下の脛骨の骨皮質を含め て切除し, 傊部を双荎皮弁で被覆，皮弁の移

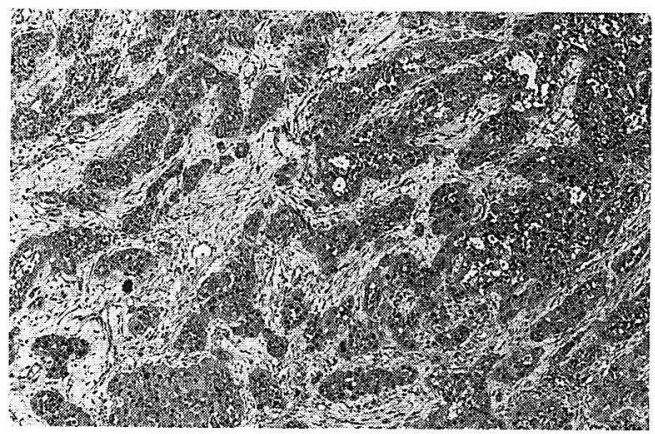

図 4.転移巣強拡大像

ヘマトキシリン, エオジン染色. 管腔様構造 を示し，左踵部と同様の所見を示す

動により生じた欠損部に分層植皮術を行った。 切除標本は, 広範な変性壊死を認め, 組織学的 に腫瘍細胞の残存を認めなかったが，左浅鼠径 リンパ節の1つに転移を認めたため, 左鼠径領 域に44.6Gy のコバルト照射を追加した。術後経 過は良好で，9月 22 日に退院した。術後 5 年を 経過し，再発・転移を認めていない。

\section{考察}

温熱療法は, $43^{\circ} \mathrm{C}$ 前後の加温による細胞障害 作用を利用した治療法である。腫瘍細胞は正常 組織に比べ血液の供給が少なく低酸素状態にあ る。このような低酸素状態で代謝が行われる と, 乳酸が産生され低 $\mathrm{pH}$ の細胞環境になり, 癌細胞が選択的に障害される3゙。また腫瘍部は 温度に対する血管反応性が悪く, 熱がうっ滞し やすいことから腫瘍部分の温度が上昇し, 腫瘍 に選択的な障害効果が得られる ${ }^{4)}$ 。それに加え， 温熱療法は放射線効果の増強作用および細胞周 期上の相補性をもつ。つまり温熱療法は，放射 線抵抗性の大きい $\mathrm{S}$ 期後半の細胞に対して強い 障害作用をもつという特徵がある ${ }^{51}$ 。以上の点 から温熱療法は臨床的に放射線療法と併用して 用いられ，すぐれた効果が認められている6”。

表在性腫瘍は加温と温度計測が比較的容易で あるため，温熱放射線療法のよい適応である。 
皮膚科領域では有棘細胞癌, メルケル細胞癌, 悪性黒色腫で温熱放射線療法が試みられ，有効 性が報告されている7) 9)。

汗腺癌に温熱放射線療法を行った症例の報告 は少なく，調べ得た限り 2 例のみである ${ }^{10) 11 。}$

自験例は, 温熱放射線療法が奏効し, 腫瘍が 肉眼的にほほ消失し，縮小手術が可能となっ た。汗腺癌の進行例や切除不能例では, 温熱放 射線療法が治療の選択肢の一つになりうると考 えられた。

\section{文献}

1) Mehregan $\mathrm{AH}$, Hashimoto $\mathrm{K}$, Rahbari $\mathrm{H}$ : Eccrine adenocarcinoma. Arch Dermatol, 119 : 104-114, 1983

2) Whittington R, Browning ME, Farrel GR, et al : Radiation therapy and chemotherapy in malignant sweat gland tumors. J Am Acad Dermatol, 15 : 1093-1097, 1986

3) Song CW, Kang MS, Rhee JG, et al : The effect of hyperthermia on vascular function $\mathrm{pH}$ and cell survival. Radiology, 137(3): 795-803, 1980

4) Song CW : Effect of local hyperthermia on blood flow and microenvironment. Cancer Research, 44 : 4721-4730, 1984

5) Westra A, Dewey WC : Variation in sensitivity to heat shock during the cell cycle of chinese hamster cells in vitro. Int J Radiat Biol, 19 : 467-477, 1971

6) Dewey WC, Hopwood LE, Sapareto SA, et al : Cellular responses to combinations of hyperthermia and radiation. Radiology, 123(2) :463-474, 1977

7）山崎隆治, 神谷秀喜, 北島康雄, 他：下口唇の巨 大有棘細胞癌の I例．皮膚臨床，42(7): 1045-1048, 2000

8）石原和之, 早坂健一, 池川修一, 他：皮膚領域に おける放射線温熱併用療法. 皮虐病診療，8(2)： 173-176, 1986

9）柄川順：悪性腫瘍の温熱療法．皮膚病診療，8(2)： $125-132,1986$

10）山崎直也, 早坂健一, 石原和之: 化学療法が有効 であった汗腺癌の 1 例. Skin Cancer, 6(3) : 380383, 1992

11）藤本良太, 永田靖, 木梨友子, 他 : 温熱併用放射 線療法が有効であった再発皮虐汗腺癌の 1 例. 癌 の臨床, 36(14): 2485-2490, 1990 